\title{
PERANAN LEMBAGA SWADAYA MASYARAKAT (LSM) \\ TERHADAP PENANGANAN KASUS TINDAK PIDANA KEKERASAN SEKSUAL PADA ANAK
}

\author{
Oleh: \\ Maurice Siburian \\ Arozatulo Maendrofa \\ Universitas Darma Agung, Medan \\ E-mail: \\ maurice rogers@yahoo.com \\ aromendrofa463@gmail.com
}

\begin{abstract}
Non-Governmental Organizations (NGOs) handling criminal cases of sexual violence against children is very important. The role of NGOs in conducting advocacy and other services for victims of sexual violence against children aims to fulfill the rights of children mandated in child protection law. The development of technology also causes various types of crimes that can occur to everyone, including children. The number of crimes of sexual violence against children, which continues to increase every year, is evidence that the imposition of crimes for sexual crimes against children cannot be said to create a deterrent effect for the perpetrator or someone who wants to commit it. The method used in this research is normative legal research method. Based on the research and discussion carried out by the author in the role of non-governmental organizations in handling criminal cases of sexual violence against children who carry out legal advocacy against children as victims of sexual violence to take care of their rights, in addition non-governmental organizations (NGOs) carry out assistance to victims such as counseling services to strengthen and provide a sense of security for victims who have suffered trauma and its mental and psychological consequences so that counseling is very helpful in restoring the victim's self-confidence.
\end{abstract}

\section{Keywords: Children, Sexual Violence, Non-Governmental Organizations (NGOs)}

\begin{abstract}
ABSTRAK
Peranan Lembaga Swadaya Masyarakat (LSM) terhadap penanganan kasus tindak pidana kekerasan seksual pada anak sangat penting. Peranan LSM dalam melakukan advokasi dan pelayanan lainnya terhadap korban kekerasan seksual pada anak bertujuan untuk memenuhi hak-hak anak sebagaimana diamanatkan dalam undang-undang perlindungan anak. Perkembangan teknologi juga membuat maraknya berbagai jenis tindak kejahatan yang dapat terjadi kepada setiap orang termasuk anak. Kejahatan kekerasan seksual pada anak yang terus meningkat setiap tahunnya merupakan bukti bahwa pemberlakuan hukuman bagi pelaku
\end{abstract}


kejahatan seksual terhadap anak masih belum dapat dikatakan sebagai hukuman yang membuat efek jera bagi pelaku ataupun seseorang yang ingin melakukannya. Metode yang digunakan dalam penelitian ini menggunakan metode penelitian hukum normatif. Berdasarkan penelitian dan pembahasan yang dilakukan penulis yakni peranan lembaga swadaya masyarakat terhadap penanganan kasus tindak pidana kekerasan seksual pada anak yaitu melakukan advokasi hukum terhadap anak sebagai korban kekerasan seksual untuk memenuhi hak-haknya, selain itu Lembaga Swadaya Masyarakat (LSM) melaksanakan pendampingan kepada korban seperti pelayanan konseling untuk menguatkan dan memberikan rasa aman bagi korban pemerkosaan yang menderita trauma dan berakibat pada mental dan psikisnya sehingga adanya konseling sangat membantu untuk memulihkan mental dan mengembalikan rasa percaya diri korban.

\section{Kata Kunci : Anak, Kekerasan Seksual, lembaga Swadaya Masyarakat (LSM)}

\section{PENDAHULUAN}

Anak merupakan aset bangsa, sebagai bagian dari generasi muda anak berperan strategis sebagai penerus suatu bangsa. Peran strategis ini telah disadari oleh masyarakat Internasional untuk melahirkan sebuah konvensi yang intinya menekankan posisi anak sebagai makhluk sosial yang harus mendapatkan perlindungan atas hakhak yang dimilikinya. Kekerasan terhadap anak merupakan permasalahan yang cukup kompleks, karena mempunyai dampak negatif yang serius, baik bagi korban maupun lingkungan sosialnya. Kekerasan juga merupakan suatu bentuk tindakan yang dilakukan satu individu terhadap individu lain yang mengakibatkan gangguan fisik dan atau mental.

Hal ini bertentangan dengan amanat Pasal 4 Undang-Undang Nomor 35 Tahun 2014 tentang Perubahan Atas Undang-Undang Nomor 23 Tahun 2002 tentang Perlindungan Anak yang menyebutkan bahwa: "Setiap anak berhak untuk dapat hidup, tumbuh, berkembang, dan berpartisipasi secara wajar sesuai dengan harkat dan martabat kemanusiaan, serta mendapat perlindungan dari kekerasan dan diskriminasi”.

PKPA mencatat kekerasan anak baik fisik maupun seksual terus meningkat, dikutip dari Metro Siantar, 24 Juli 2017. Misran Lubis sebagai Senior Officer PKPA mengungkapkan data dari jaringan perlindungan anak Sumut tahun 2016 tercatat ada 196 kasus kekerasan dan eksploitasi menimpa anak. Dari jumlah itu, kekerasan seksual berada diurutan teratas dengan 75 kasus. Dimana anak sebagai korban terbanyak 69 perempuan dan 6 lakilaki. Pada urutan kedua adalah kasus anak sebagai pelaku tindak pidana dengan 53 kasus yang semuanya adalah laki-laki. Pada urutan ketiga terdapat kekerasan fisik dengan 43 kasus, diantara korbannya terdapat 31 orang laki-laki dan 12 orang perempuan. Selama tahun 2017 kasus kejahatan dan kekerasan terhadap anak di Sumatera Utara mengalami peningkatan drastis. 
Direktur Pusat Kajian dan Perlindungan Anak (PKPA) Sumut, Misran Lubis di Medan mengatakan berdasarkan advokasi dan pemantauan selama ini mencatat adanya 295 kasus kejahatan pada anak di tahun 2017.

\begin{tabular}{lrr}
\multicolumn{3}{c}{ Berdasarkan data diatas } \\
penulis tertarik & untuk meneliti \\
tentang judul & (PERANAN \\
LEMBAGA & SWADAYA \\
MASYARAKAT & (LSM) \\
TERHADAP PENANGANAN \\
KASUS TINDAK PIDANA \\
KEKERASAN SEKSUAL PADA \\
ANAK (Studi Putusan No. \\
9/Pid.Sus/2016/PN Gst).
\end{tabular}

\section{TINJAUAN PUSTAKA}

1. Pengertian anak

Terdapat beberapa perundangundangan yang berlaku di Indonesia saat ini yang mengatur tetntang pengertian anak berdasarkan umur. Batasan umur seseorang masih dalam kategori anak, berdasarkan beberapa peraturan yang ada di Indonesia cukup beragam, yang antara lain adalah sebagai berikut:

a) Pasal 1 angka 1 Undang-Undang No. 3 Tahun 1997 tentang Pengadilan Anak, menyatakan bahwa anak adalah orang yang dalam perkara anak nakal telah mencapai umur 8 (delapan) tahun tetapi belum mencapai 18 (delapan belas) tahun dan belum pernah kawin;

b) Pasal 1 angka 5 Undang-Undang No. 39 Tahun 1999 tentang Hak Asasi Manusia, menyatakan bahwa bahwa anak adalah setiap manusia yang berusia dibawah 18 (delapan belas) tahundan belum menikah, termasuk anak yang masih dalam kandungan apabila hal tersebut adalah demi kepentingannya; dan

c) Pasal 1 angka 1 Undang-Undang No. 23 Tahun 2002 tentang Perlindungan Anak, menyatakan bahwa anak adalah seseorang yang belum berusia 18 (delapan belas) tahun, termasuk anak yang ada dalam kandungan.

2. Tindak pidana kekerasan seksual Istilah kekerasan, dalam Kamus Besar Bahasa Indonesia (KBBI) memiliki arti sesuatu yang memiliki sifat keras, atau adanya sebuah paksaan dalam suatu perbuatan seseorang atau sekelompok orang yang menyebabkan kerusakan fisik atau suatu barang. Sedangkan secara harfiah, kekerasan adalah wujud perbuatan yang lebih bersifat fisik, yang dapat menimbulkan luka, cacat, sakit, atau penderitaan pada orang lain, dimana terdapat unsur paksaan atau ketidakrelaan atau tidak adanya persetujuan dari orang lain.

3. Lembaga Swadaya Masyarakat

Lembaga Swadaya Masyarakat (LSM) adalah sebuah organisasi yang didirikan oleh perorangan ataupun sekelompok orang yang secara sukarela yang memberikan pelayanan kepada masyarakat umum tanpa bertujuan untuk memperoleh keuntungan dari kegiatannya.

\section{METODE}

\section{PELAKSANAAN}

$\begin{array}{lcr}\text { Penelitian } & \text { yang } & \text { berjudul } \\ \text { "Peranan } & \text { Lembaga } & \text { Swadaya } \\ \text { Masyarakat } & \text { (LSM) } & \text { Terhadap } \\ \text { Penanganan } & \text { Kasus Tindak } & \text { Pidana } \\ \text { Kekerasan } & \text { Pada } & \text { Anak" }\end{array}$ menggunakan jenis penelitian hukum normatif. Penelitian hukum normatif atau penelitian hukum kepustakaan ini mencakup penelitian terhadap 
asas-asas hukum, penelitian terhadap sistematika hukum, perbandingan hukum dan sejarah hukum. Penelitian hukum normatif atau penelitian perpustakaan ini merupakan penelitian yang mengkaji studi dokumen yaitu studi kasus pada Putusan Pengadilan Negeri Gunung Sitoli (Studi Putusan No. 9/Pid.Sus/2016/PN Gst)"

Analisis data pada penelitian ini menggunakan analisis interprestasi dan silogisme untuk memaparkan atau menjelaskan persoalan hukum yang diteliti, memberi komentar dan kemudian membuat suatu kesimpulan terhadap hasil penelitian dengan pikiran sendiri dengan bantuan teori.

IV. HASIL

DAN

PEMBAHASAN

\section{A. Faktor-Faktor Penyebab Terjadinya Tindak Pidana Kekerasan Seksual Pada Anak}

a. Faktor Internal Terjadinya Kekerasan Seksual Pada Anak. Bahwa kekerasan terhadap anak umumnya disebabkkan oleh faktor internal yang berasal dari anak sendiri yaitu anak mengalami cacat tubuh, retardasi mental, gangguan tingkah laku autisme, anak terlalu lugu, memiliki temperamen lemah, ketidaktahuan anak mengenai hak-haknya, anak terlalu bergantung pada orang dewasa.

b. Faktor eksternal terjadinya kekerasan seksual pada anak, yaitu

a. Kemiskinan keluarga, orang tua menganggur, penghasilan tidak cukup dan banyak anak b. keluarga tunggal atau keluarga (broken home), misalnya peceraian, ketiadaan ibu untuk jangka panjang atau keluarga tanpa ayah dan ibu tidak mampu memenuhi kebutuhan anak secara ekonomi;

c. Keluarga yang belum matang secara psikologis, ketidaktahuan mendidik anak, harapan orang tua yang tidak reallistis, anak yang tidak diinginkan (unwanted child), anak yang lahir diluar nikah;

d. Penyakit parah atau gangguan mental pada salah satu atau kedua orang tua, misalnya tidak mampu merawat dan mengasuh anak karena gangguan emosional dan defresi;

1. Sejarah penelantaran anak, orang tua yang merasa kecilnya mengalami perlakuan salah cenderung memperlakukan salah anak-anaknya;

2. Kondisi lingkungan sosial yang buruk, permukiman kumuh, tergusurnya tempat bermain anak, sikap acuh tak acuh terhadap tindakan eksploitasi, pandangan terhadap nilai anak yang terlalu rendah, meningkatnya faham ekonomi upah, lemahnya perangakat hukum, tidak adanya mekanisme kontrol sosial yang stabil.

\section{B. Peranan Lembaga Swadaya Masyarakat (LSM) Terhadap Penanganan Kasus Tindak Pidana Kekerasan Seksual Pada Anak}

Salah satu Lembaga Swadaya Masyarakat (LSM) di Sumatera 
Utara yang bergerak dibidang perlindungan anak adalah Pusat Kajian Perlindungan Anak (PKPA). PKPA adalah yayasan masyarakat sipil yang merupakan bagian dari masyarakat yang tidak memiliki mandat secara konstitusi, jadi PKPA merupakan organisasi yang berpartisipasi atau ikut serta dalam mewujudkan hak-hak anak yang belum terpenuhi. PKPA mempunyai peran sebagai berikut :

1. Memberikan perlindungan terhadap anak dari setiap orang atau yayasan yang melakukan pelanggaran terhadap hak anak.

2. Melakukan kajian dan penelitian terhadap permasalahan anak serta mencari solusi atas persoalan tersebut.

3. Melakukan kerjasama dengan yayasan/instansi lain serta masyarakat untuk melakukan advokasi terhadap permasalahan anak.

4. Menyediakan layanan informasi kepada masyarakat tentang hakhak anak dengan benar.

5. Memberikan layanan langsung kepada anak dalam rangka pemenuhan hak-haknya.

6. Memperjuangkan terciptanya kepentingan yang terbaik bagi anak dengan advokasi kebijakan yang diperlukan untuk meningkatkan kesejahteraan dan perlindungan anak serta menegakkan hak-hak anak.

Namun, disisi lain PKPA melakukan 4 hal, yaitu :

1. Kajian untuk memberikan rekomendasi kepada negara tentang kondisi anak yang harus ditangani.

2. Melakukan penyadaran kepada masyarakat, bahwa anak-anak yang ada dikeluarga mereka, anak-anak bersama mereka seutuhnya bukan milik mereka, bahwa anak-anak tersebut juga milik masyarakat, milik bangsa dan negara.

3. Ikut berpartisipasi memberi layanan-layanan yang mungkin belum terpenuhi oleh negara atau belum sepenuhnya dipenuhi dan PKPA hadir untuk memberi layanan seperti layanan pendidikan, hukum, kesehatan dan sebagainya.

4. Mengajak kaum muda, anakanak untuk ikut berpartisipasi dalam berbagai macam kegiatan sehingga mereka dalam situasi apapun memiliki kesempatan untuk bermain dengan teman sebayanya.

\section{KESIMPULAN}

Berdasarkan hasil penelitian yang telah dilakukan dan dijabarkan oleh peneliti, maka peneliti menyimpulkan hal-hal sebagai berikut :

1. Faktor-faktor penyebab terjadinya tindakan kekerasan seksual terhadap anak adalah kurangnya pengawasan orang tua, kurangnya perhatian dan kedekatan orang tua terhadap anak, status ekonomi, pengaruh lingkungan. Selain itu ada juga faktor internal dan eksternal terjadinya tindakan seksual terhadap anak yaitu sebagai berikut :

a. Faktor internal : masalah mental, cacat fisik dan gen.

b. Faktor eksternal : narkotika, orang tua penangguran, perceraian orang tua, status ekonomi, minum minuman beralkohol, pergaulan bebas dan lingkungan. 
2. Peranan Lembaga Swadaya Masyarakat (LSM) terhadap penanganan kasus tindak pidana kekerasan seksual pada anak yaitu melakukan advokasi hukum terhadap anak sebagai korban kekerasan seksual untuk memenuhi hak-haknya, selain itu Lembaga Swadaya Masyarakat (LSM) melaksanakan pendampingan kepada korban seperti pelayanan konseling untuk menguatkan dan memberikan rasa aman bagi korban pemerkosaan yang menderita trauma dan berakibat pada mental dan psikisnya sehingga adanya konseling sangat membantu untuk memulihkan mental dan mengembalikan rasa percaya diri korban.

\section{DAFTAR PUSTAKA}

\section{A. Buku-Buku}

Arief, B. N. (1998). Beberapa aspek kebijakan penegakan dan pengembangan hukum pidana. Citra Aditya Bakti.

Diniyanti, N., \& Sidemen, I. G. Hubungan Kekerasan Dalam Rumah Tangga Yang Dilakukan Suami Pada Istri Dengan Perilaku Kekerasan Ibu Pada Anak.

Djiwandon, S. E. W. (1989). Psikologi Pendidikan (rev-2). Grasindo.

Edi Suharto, Pekerjaan Sosial di Bidang Industri,Bandung, Refika ADITAMA : 2007.

Fursiyana, W. (2015). Child Abuse (Kekerasan Terhadap Anak) Dalam Perspektif Pendidikan Islam (Studi Deskriptif Buku" Kekerasan Terhadap
Anak" Karya Abu Huraerah, M. Si.).

Husodo, B. D. Upaya Lembaga Swadaya Masyarakat (Lsm) Rifka Annisa Dalam Memberikan Perlindungan Terhadap Korban Pemerkosaan.

Hufad Perilaku kekerasan: analisis menurut sistem budaya dan implikasi edukatif., A. (2003). Mimbar Pendidikan, 22(2), 52-61.

I.S.Susanto, (Yogyakarta:Genta Publishing, 2011)

Ilyas, A. (2012). Asas-asas Hukum Pidana. Rangkang Education \& PuKab, Yogyakarta.

Imam, K., Nuh, M., \& Mulyadi, M. (2013). Penegakan Hukum Terhadap Tindak Pidana Perkosaan Dan Penganiayaan Yang Dilakukan Oleh Anak Dibawah Umur (Studi Putusan Pengadilan Negeri Medan No. 3.372/Pid. B/2010/PN. Mdn). Jurnal Mahupiki, 1(1).

Kansil, C. S. T., \& Kansil, C. S. (2010). Latihan Ujian Hukum Pidana Untuk Perguruan Tinggi. Jakarta: Sinar Grafika.

Marpaung, L. (2004). Kejahatan Terhadap Kesusilaan dan Masalah Prevensinya, cet 2. Jakarta: Siunar Grafika

Mahju Muljono, Pengantar Teori Kriminologi.

(Yogyakarta:Pustaka Yustisia, 2012) 
B. Perundang-Undangan

Undang-Undang No. 35 Tahun 2014 Jo Undang-Undang No. 23 Tahun 2002 Tentang Perlindungan Anak.

Undang-Undang No. 3 Tahun 1997 Tentang Pengadilan Anak

Undang-Undang No. 39 Tahun 1999 Tentang Hak Asasi Manusia

Undang-Undang No. 11 Tahun 2012 Tentang Sistem Peradilan Pidana Anak

Undang-Undang No. 18 Tahun 2003 Tentang Advokat.

Peraturan Pemerintah No. 35 Tahun 2020 Tentang Pemberian Kompensasi, Restitusi dan Bantuan Hukum Kepada Saksi dan Korban.

Keputusan Presiden No. 36 Tentang Pengesahan Konvensi Tentang Hak-Hak Anak.

\section{Internet}

Metro Siantar, Orangtua Pelaku Kekerasan Pada Anak

Terbanyak di Sumut.

http://www.metrosiantar.com/news/s umut/2017/07/24/260374/ora ngtuapelakukekerasanpadaan akterbanyakdisumut/.

Diakses pada tanggal 20

Februari 2020

Ridin,Waspada.co,id/sumut/pkpa2017-kasus-kejahatan-anakmeningkat-drastis /2018 / januari/01/. Diakses pada tanggal 20 Februari 2020 